\title{
Satellite retrieval of mass balance: comparing SAR images with albedo images and in situ mass-balance observations
}

\author{
Martijn S. DE RUYTER DE WILDT, Johannes OERLEMANS \\ Instituut voor Marien en Atmosferisch Onderzoek, Universiteit Utrecht, Princetonplein 5, 3584 CC Utrecht, The Netherlands \\ E-mail: wildt@phys.uu.nl
}

\begin{abstract}
We present an analysis of many European Remote-sensing Satellite (ERS) synthetic aperture radar (SAR) images of Vatnajökull, Iceland, by comparing them with Advanced Very High Resolution Radiometer (AVHRR) images, massbalance observations and modelled firn stratigraphy. Summer SAR and AVHRR images both detect the surface firn line (or the transient snow-line when it lies below the firn line) as a distinct boundary. Winter SAR images of Vatnajökull generally display the late-summer surface firn line, and often also a transition at a higher elevation that possibly reflects a subsurface continuation of the firn line. On some winter images the firn line is not adequately detected, possibly due to a shallow firn pack. We found no differences in backscatter between melting snow and firn, and for most years no differences in reflectance either. For Vatnajökull, equilibrium-line altitude is therefore not a particularly useful estimator of the mean specific mass balance $\left(B_{\mathrm{m}}\right)$. Unlike albedo images, SAR images do not display interannual variations of the signal within the accumulation area that are clearly related to $B_{\mathrm{m}}$. Hence, SAR images of Vatnajökull contain less information about $B_{\mathrm{m}}$ than albedo images. However, for some drainage basins, mean transient snow-line/firn-line altitude during the melting season can be used to infer $B_{\mathrm{m}}$.
\end{abstract}

\section{INTRODUCTION}

Glaciers and ice caps often lie in remote areas, are difficult to access and can have vast surface areas. Direct observation of the mean specific mass balance $\left(B_{\mathrm{m}}\right)$ and related quantities, such as the equilibrium-line altitude (ELA) and the accumulation-area ratio, is therefore a time-consuming and often costly procedure. As a consequence, these quantities have been measured on relatively few glaciers worldwide. Larger parts of the cryosphere can be studied on a regular basis with satellite sensors. Østrem (1975) proposed that the often-found linear relation between $B_{\mathrm{m}}$ and ELA can be used to infer $B_{\mathrm{m}}$ by using satellite-derived ELA. In recent years, much work has been devoted to inferring the snowline at the end of the melting season. Note that we define firn as snow that has survived at least one summer, which implies that the equilibrium line equals the snow-line at the end of the melting season (if there is no superimposed ice). Some authors successfully applied Østrem's method by using satellite albedo images (e.g. Rott and Markl, 1989) or synthetic aperture radar (SAR) images (e.g. Demuth and Pietroniro, 1999), but the method often fails. This can occur when the equilibrium line lies above its position of the previous year $(\mathrm{s})$. In such cases the snow-line is sometimes visible (e.g. Rott and Markl, 1989), but often the difference in albedo $(\alpha)$ between firn and snow several months old is too small to be detectable (e.g. Rott and Markl, 1989; Hall and others, 1995; De Ruyter de Wildt and others, 2002). Then, only the firn line can be detected. De Ruyter de Wildt and others (2002) developed a method that does not suffer from this problem. The net potential shortwave radiation, defined as the net shortwave radiation at the top of the atmosphere, can be calculated from albedo images. This quantity, integrated over the glacier surface and over the melting season, is a measure of the amount of absorbed shortwave radiation. Consequently, it both influences and depends on summer melt (due to ageing of snow and firn and meltwater effects) and also depends on summer snowfall. It also depends on winter mass balance and was found to be linearly related to $B_{\mathrm{m}}$ for Vatnajökull, Iceland. Unfortunately, in some years high cloudiness limited the availability of albedo images and hence introduced uncertainty into this linear relationship.

Clouds do not pose a problem when SAR backscatter images are used. Backscatter $\left(\sigma_{0}\right)$ images can display several boundaries, which correspond to surface or subsurface facies transitions. Microwaves penetrate through dry snow, so the main signal over dry snow surfaces originates from subsurface material (e.g. Rott and others, 1985). The underlying material in the ablation area is ice, which produces less backscatter than the underlying firn in the accumulation area. Firn contains scattering elements such as ice structures and internal surfaces. SAR images acquired in winter or early spring can therefore be used to detect the boundary between ice and snow/firn (e.g. Fahnestock and others, 1993; Hall and others, 1995; Partington, 1998; König and others, 2001). When the surface is melting, the $\sigma_{0}$ signal is much lower and stems from the top few $\mathrm{cm}$ (e.g. Stiles and Ulaby, 1982), meaning that only surface features can be observed. It also means that the boundary between dry and wet snow is detectable (e.g. Steffen and others, 1993), as well as the boundary between bare ice and wet snow or firn (e.g. Rott and Mätzler, 1987; Adam and others, 1997). Smith and others (1997) also observed a fourth zone, marked by 


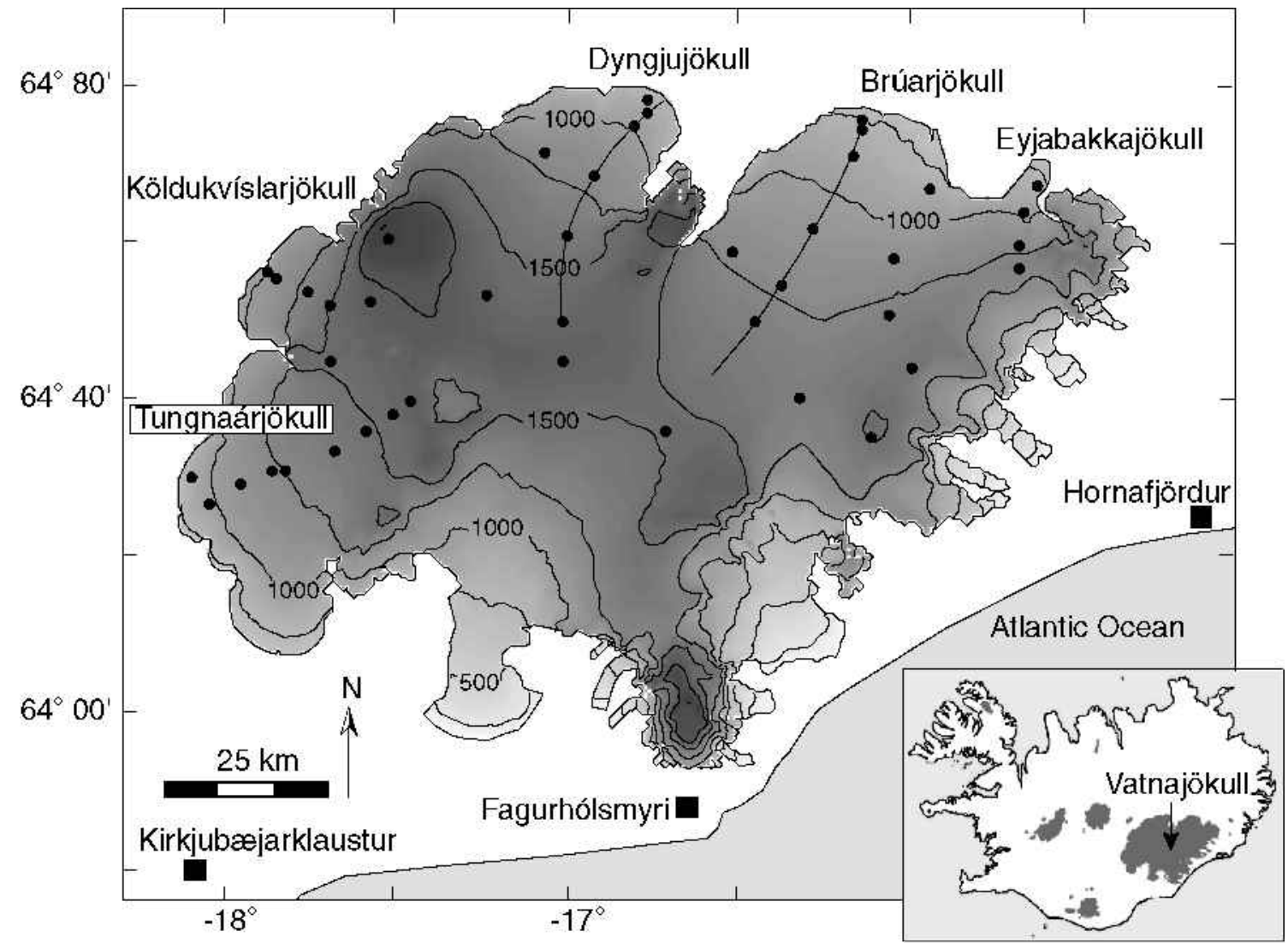

Fig. 1. Map of Vatnajökull, based on the DEM used for image processing. The DEM has a horizontal resolution of $500 \mathrm{~m}$. Height contours are shown for each $250 \mathrm{~m}$ interval. Outlets where the mass balance has been regularly measured are indicated. The black circles represent sites where the mass balance has been measured. Over western Brúarjökull and over Dyngjujökull, transects through measurement sites are shown.

high backscatter over wet snow (phase 2 melt or P2), which is most likely caused by roughness due to suncups (Ramage and others, 2000). These four zones (dry snow, wet snow, metamorphosed wet snow and ice) were seen to move upglacier and replace each other during the melting season. In spite of these observations, SAR images have been compared to in situ mass-balance observations only a few times (e.g. Demuth and Pietroniro, 1999; Hall and others, 2000; König and others, 2001), while a comparison of radar images with mass-balance measurements and/or albedo images from a number of years has yet to be made. From the latter two studies it appears that, as is often the case for albedo images, the $\sigma_{0}$ signal cannot distinguish between snow and firn. Consequently, the snow-line appears only to be visible on radar images when no firn is present at the surface.

For Vatnajökull, one of the largest temperate ice caps in the world, a wealth of information is available with which SAR images can be analyzed and interpreted. A digital elevation model (DEM) is available (Fig. 1) and its mass balance has been regularly measured (e.g. Björnsson and others, 1998c). Recently a mass-balance model was developed and calibrated to the conditions on the ice cap (De Ruyter de Wildt and others, 2003). The mass-balance measurements have been compared to U.S. National Oceanic and Atmospheric Administration (NOAA) Advanced Very High Resolution Radiometer (AVHRR) images (De Ruy-

Table 1. Mean specific mass balance of various drainage basins of Vatnajökull (in m w.e.)

\begin{tabular}{|c|c|c|c|c|c|c|c|}
\hline Tear & Western Brúarjökull & Eastern Brúarjökull & Eyjabakkajökull & Dyngjujökull & Köldukvislarjökull & Tungnaárjökull & All \\
\hline 1991 & & & -0.90 & & & & \\
\hline 1992 & & & & & 0.81 & 0.35 & \\
\hline 1993 & 1.32 & 0.89 & 0.69 & 1.58 & & 0.23 & 1.16 \\
\hline 1994 & 0.55 & & 0.42 & 0.36 & 0.03 & -0.11 & 0.31 \\
\hline 1995 & 0.22 & & -0.48 & 0.04 & -0.64 & & -0.31 \\
\hline 1996 & -0.04 & -0.76 & -0.88 & -0.21 & -0.68 & & -0.54 \\
\hline 1997 & -1.04 & -1.79 & -1.88 & -0.85 & -1.07 & -2.18 & -1.30 \\
\hline 1998 & -0.46 & -0.94 & -1.57 & -0.53 & -0.80 & -1.53 & -0.77 \\
\hline 1999 & -0.09 & -0.56 & -0.72 & & -0.58 & -0.99 & -0.26 \\
\hline
\end{tabular}

Notes: The values were obtained by interpolation. The weighted mean for the whole northwestern part of Vatnajökull (All) is shown when the mass balance was measured over the largest part of this area. 
Table 2. ERS SAR images and NOAA AVHRR images used in this work

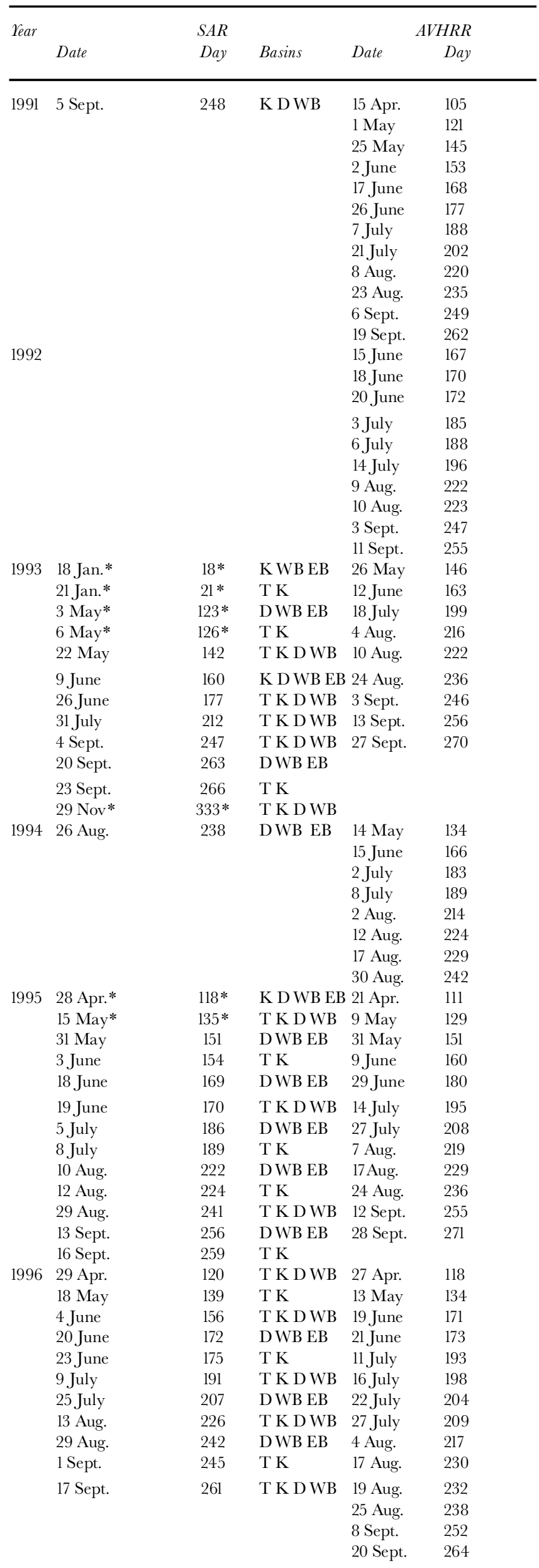

Table 2 cont.

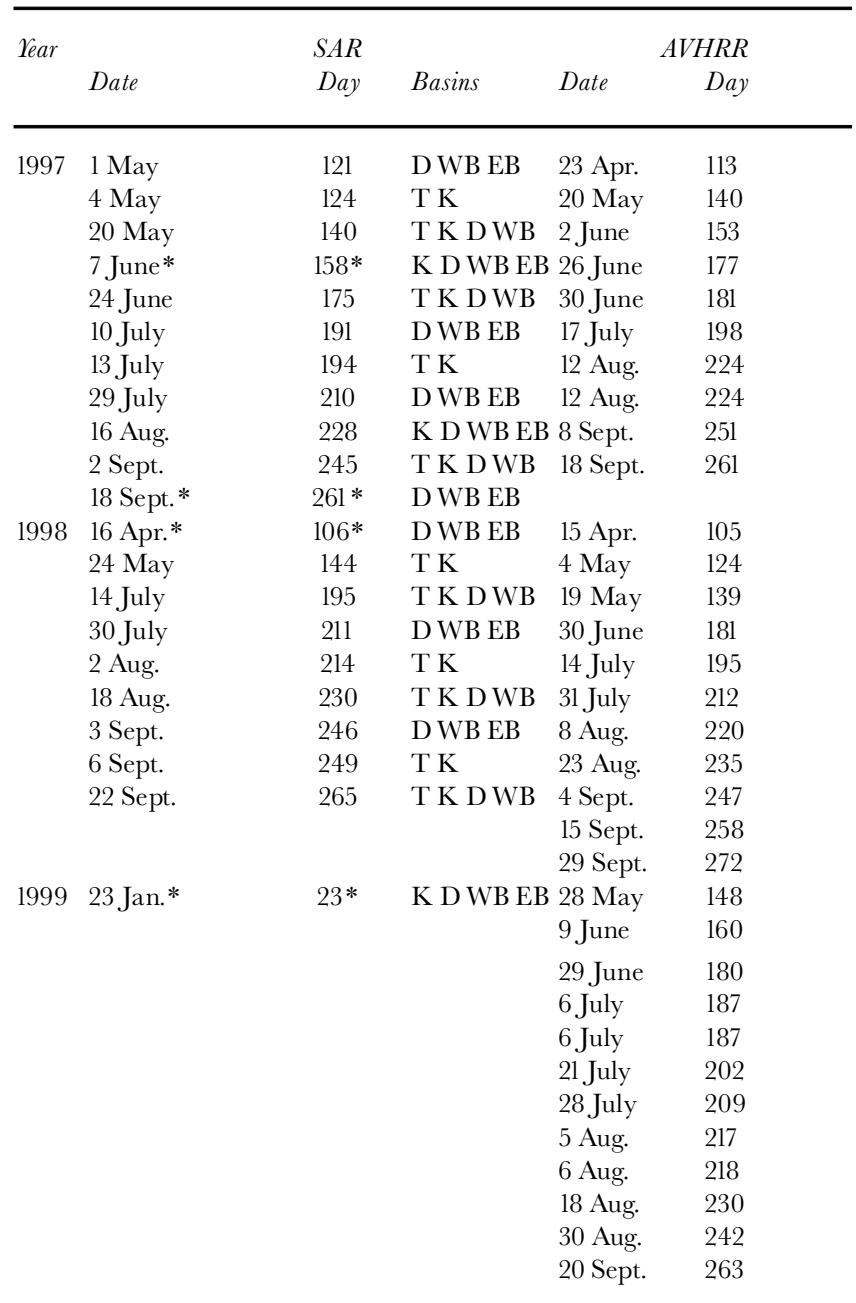

Notes: SAR images that were acquired during freezing conditions over the northern and western part of Vatnajökull are marked *. The "basins" column shows which of the drainage basins Tungnaárjökull (T), Köldukvislarjökull (K), Dyngjujökull (D), western Brúarjökull (WB) and eastern Brúarjökull (EB) are displayed on the SAR images.

ter de Wildt and others, 2002). In situ mass-balance measurements, NOAA AVHRR images and a long-term modelled mass-balance series form a unique dataset with which SAR images can be compared. In this paper we do so for eight melting seasons in the 1990s. We also use some images that were acquired during freezing conditions. First we directly compare SAR images with AVHRR images to identify glacier facies. Then we reconstruct the stratigraphy of a part of Vatnajökull from measured and modelled massbalance values, in order to explain several boundaries and structures that are visible on SAR and AVHRR images. On the basis of these investigations, we discuss some possible ways of retrieving the mass balance from SAR images.

\section{DATA}

\subsection{Mass-balance observations}

The mass balance of Vatnajökull has been measured with good spatial resolution since 1992 (Björnsson and others, 1997, 1998a, b, c, 1999; Sigurðsson, 1999; personal communication from O. Sigurðsson). The data have mainly been obtained over the drainage basins of Eyjabakkajökull, 
Brúarjökull, Dyngjujökull, Köldukvíslarjökull and Tungnaárjökull (Fig. 1). For Eyjabakkajökull, data from 1991 are also available. Most measurements were taken at the end of September or the beginning of October. On each outlet, the mass balance has been measured along one or two profiles that capture the altitudinal variation. Because most of Vatnajökull is quite flat, the profiles can be used together with a few additional measurement sites to describe the lateral variation. We obtain the mean specific balances of the drainage basins and the ELAs by interpolating between the measurement sites. For this interpolation, we developed an algorithm that takes into account vertical gradients in the mass balance, even when these are not resolved by the measurement sites. A DEM is needed for this feature to work. For each gridpoint of the DEM, the algorithm determines the $n$ closest measurement sites within $500 \mathrm{~m}$ altitude of the gridpoint. Then, because of the limited height differences, a linear relation between mass balance and altitude is found for the $n$ measurement sites, with which the mass balance at the gridpoint can be calculated. To smooth discontinuities in the resulting mass-balance field, the contribution of each measurement site is weighted with the inverse of its distance to the gridpoint. The resulting values of $B_{\mathrm{m}}$ are not very sensitive to the value of $n$. We therefore use a value of 6 , which is the lowest value that gives smooth mass-balance fields. Table 1 displays the resulting values of $B_{\mathrm{m}}$. The data include years with a highly positive $B_{\mathrm{m}}(1992,1993)$ and years with a highly negative $B_{\mathrm{m}}(1997,1998)$. We estimate the uncertainty in $B_{\mathrm{m}}$ to be $0.25 \mathrm{~m}$ w.e.

\subsection{ERS SAR images}

The European Space Agency (ESA) launched the first European Remote-sensing Satellite, ERS-1, in 1991 and the second, ERS-2, in 1995. Both satellites carry a C-band $(5.3 \mathrm{GHz})$ SAR with vertical transmit-and-receive (VV) polarization. We use PRecision Image (PRI) SAR data which are three-look (speckle-reduced) and are calibrated and corrected for the SAR antenna pattern and rangespreading loss (Laur and others, 1998). The strength of the $\sigma_{0}$ signal depends upon the local incidence angle, but as most of Vatnajökull is almost flat we do not need to take the surface slope into account. The $\sigma_{0}$ signal is dimensionless and given in $\mathrm{dB}$ (i.e. on a logarithmic scale). In total we purchased 59 images, which are listed in Table 2. They were acquired year-round during much of the period 1991-99 and often display only a part of Vatnajökull. Table 2 shows which drainage basins are visible on each image. The horizontal resolution of the images is $33 \mathrm{~m}$ in range and $30 \mathrm{~m}$ in azimuth, while the pixel size is $12.5 \mathrm{~m}$. We upscale the pixel size of the ERS scenes with a factor of 10 (up to a pixel size of $125 \mathrm{~m}$ ) in order to facilitate the processing of large numbers of SAR scenes. The upscaling is allowed by the fairly large size $\left(8200 \mathrm{~km}^{2}\right)$ and low surface slopes $\left(2.8^{\circ}\right.$ on average $)$ of Vatnajökull. Furthermore, the resulting resolution is still smaller than those of the DEM $(500 \mathrm{~m})$ and the AVHRR images $(1.1 \mathrm{~km})$. The upscaling also takes care of the additional speckle filtering that is usually required for PRI images. ESA provides the horizontal coordinates of the images with an accuracy of $100 \mathrm{~m}$ in range and $200 \mathrm{~m}$ in azimuth. These coordinates refer to points that are projected on a reference geoid, and differ from the actual coordinates on the ice-cap surface (which lies above the reference geoid). We therefore localized a number of control points on each image, like nunataks and glacier margins, and compared their ESA-supplied coordinates with those of the DEM. For each image, this resulted in nearly linear relations between the displacement and the altitude. With these linear relations we could correct the coordinates of the image pixels. Judging by the uncertainties of the linear relations, we estimate that the uncertainties of the corrected coordinates are equal to one DEM element $(500 \mathrm{~m})$ in both the longitudinal and latitudinal direction.

\subsection{NOAA AVHRR images}

We purchased NOAA AVHRR images from the Dundee Satellite Receiving Station in the U.K. The images were acquired during the melting seasons (April-September) of the years 1991-99. The horizontal resolution at nadir is $1.1 \mathrm{~km}$. This resolution is quite large, but because of the size of Vatnajökull and its small surface slopes it is low enough to detect features like the firn line. Moreover, AVHRR images can be used to establish usable time series because the repeat time over Iceland is high (a few times per day), making it possible to detect the sparse cloud-free moments. In the first four years, the NOAA-11 satellite provided the data. From 1995 onwards, the images were acquired by the NOAA-14 satellite. Because Iceland lies in the North Atlantic Ocean, where storm activity is high, the skies are often overcast and most of the images display some clouds. It was therefore not always possible to find cloud-free images for the end of the melting season (e.g. in 1994 and 1999). We found 9-15 images for each melting season, with a typical time interval of 2 weeks between images (Table 2). Nearly all images were acquired near solar noon, when irradiance was high. The process of retrieving the surface albedo from the images has been discussed in detail elsewhere (De Ruyter de Wildt and others, 2002), so we restrict ourselves here to a short description of the successive processing steps:

Clouds are distinguished from snow and ice by making use of the reflective and thermal differences in AVHRR channel $3(3.5-3.9 \mu \mathrm{m})$ and the thermal differences in channel $4(10.5-11.5 \mu \mathrm{m})$ that often, but not always, exist. Not all clouds are detected in this way, so we had to check the images for errors manually. A convenient way of doing this is to compare subsequent images and look at textural characteristics.

We apply a geolocation to each image by comparing the images to the DEM. For this purpose, the images are rotated and stretched, which involves some resampling. The horizontal resolution of the DEM is smaller than the AVHRR pixel size, namely $500 \mathrm{~m}$. For most images we were able to locate the ice margin and features like mountain peaks and steep ridges with an accuracy of one pixel. The accuracy of the geolocation for a few images with a large satellite viewing angle is estimated to be two pixels.

Measured radiation intensities are calibrated with the calibration formulas of Rao and Chen $(1995,1999)$ for the AVHRR instruments aboard the NOAA-11 and NOAA-14 satellites, respectively. These coefficients take instrument drift into account. The resulting radiances are converted into planetary albedos.

We use a radiative transfer model (Koelemeijer and others, 1993) to convert the planetary albedos into sur- 


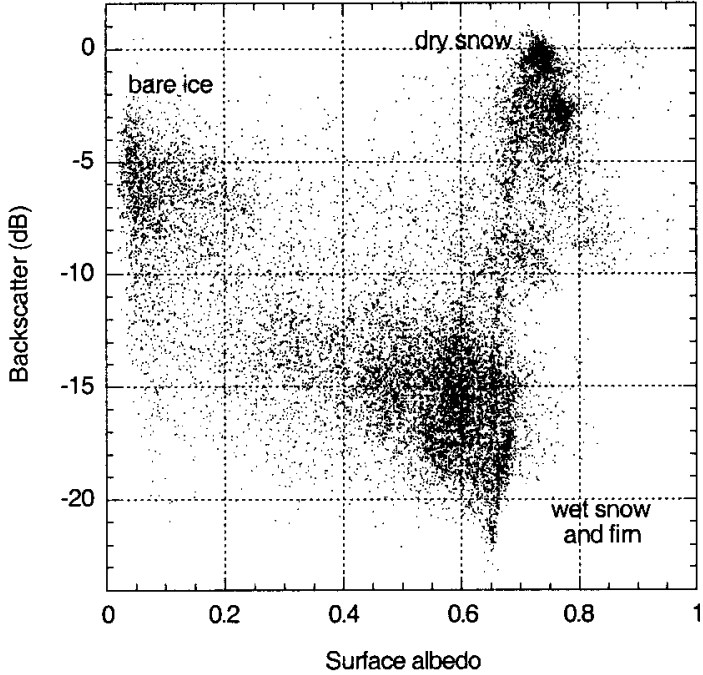

Fig. 2. Radar backscatter against satellite-derived surface albedo. Each point represents an AVHRR pixel; for this plot the backscatter images have been resampled up to the same resolution as the AVHRR images $(1.1 \mathrm{~km})$. The maximum time gap between radar and albedo images used to make this plot is 3 days. Seventeen such pairs were found, distributed randomly over the spring and summer of five years (Table 2). Two of the pairs are not used because the corresponding SAR images displayed unusual radiometric distortions.

face albedos. This model takes Rayleigh scattering and attenuation by ozone and water vapour into account but neglects the effect of aerosols. Because the results are not very sensitive to the atmospheric profiles (Reijmer, 1997), we use the standard Sub Arctic Summer Profile of McClatchey and others (1972) as input.

We employ an empirical expression to convert the surface narrowband albedos in AVHRR channels 1 and 2 into broadband albedos. This expression (De Ruyter de Wildt and others, 2002; personal communication from W. Greuell) is based on many (8000) point measurements made simultaneously in AVHRR channels 1 and 2 and over the entire solar spectrum (Greuell and others, 2002). The measurements were made over a broad range of surface types, ranging from dirty glacier ice to melting snow and having broadband albedos of $0.05-0.80$.

To correct for the anisotropic nature of reflection at snow surfaces, we apply an empirical parameterization (Koks, 2001), which is based on measurements over melting snow 2-3 weeks old, and is valid for a broad range of solar zenith angles $\left(15.9-65.5^{\circ}\right)$. During the summer, virtually all surface snow of Vatnajökull melts and becomes metamorphosed, so the parameterization is likely to be valid for the average summer conditions on Vatnajökull. We do not apply a correction for anisotropy over glacier ice, because much of the glacier ice of northern Vatnajökull is covered with black volcanic deposits (for this surface type no parameterization is available). Distinguishing between ice and snow on northern Vatnajökull is easy, due to the darkness of much of the glacier ice.

In the above, the fluxes are calculated with respect to a horizontal plane. If the surface is inclined, the fluxes through a plane parallel to the surface differ from those

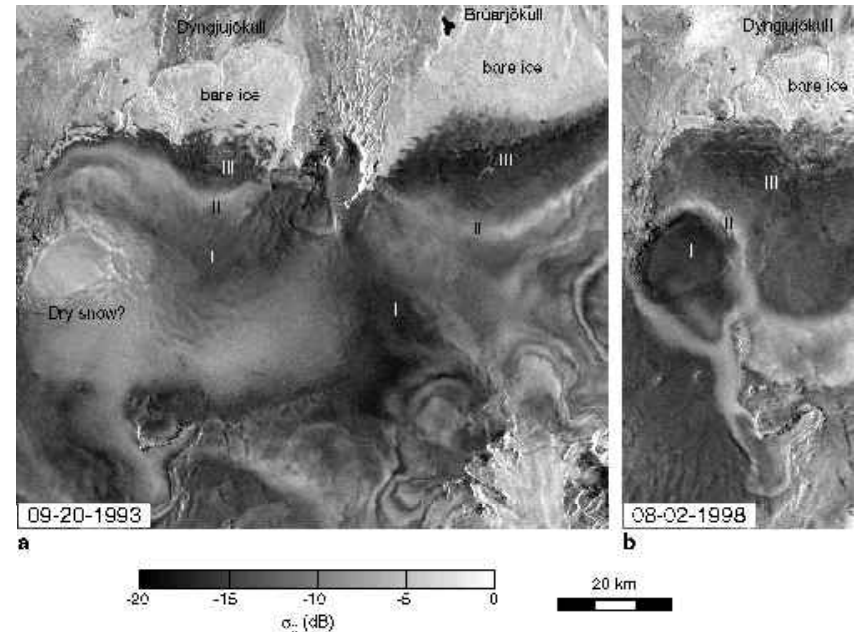

Fig. 3. ESA ERS $\sigma_{0}$ images of part of Vatnajökull, acquired on 20 September, 1993 ( a) and 2 August 1998 (b). The latter image was cut off because it displayed much of the surrounding terrain. Latin numerals indicate different zones of surface facies. (C) ESA 2002.

through the horizontal plane and a correction needs to be applied to obtain the surface albedo. We calculate the surface albedo with the expression of Knap and others (1999).

\section{INTERPRETATION OF RADAR BOUNDARIES}

A first and direct way to interpret the different $\sigma_{0}$ signatures observed on the SAR images of Vatnajökull is to make a scatter plot of $\sigma_{0}$ against $\alpha$ (Fig. 2). In this plot we clearly see three clusters of data points, representing three kinds of surface facies. Dry snow has high $\alpha$ and high $\sigma_{0}$ signatures. The difference between dry snow lying directly on top of glacier ice and dry snow lying on firn is small $(3-4 \mathrm{~dB})$ and the two groups merge in Figure 2 (note that the two subclusters of dry snow in this figure represent two different days, not the difference between ice and firn below the dry snow). Melting snow and firn have somewhat lower $\alpha$ values, but drastically lower $\sigma_{0}$ values. Some authors (Smith and others, 1997; Ramage and others, 2000) observed melting snow with high $\sigma_{0}(>-12 \mathrm{~dB})$, which they called the P2 (phase 2) melt facies. On five out of 43 SAR images of Vatnajökull with melting surfaces, we can observe such facies with high $\sigma_{0}$, but for only one of these is a simultaneous AVHRR image available. This facies is not identifiable in Figure 2 because it represents only a small part of this one pair of images. A third cluster represents bare glacier ice with much lower $\alpha$ values and rather high $\sigma_{0}$ values. For melting surfaces, there is a tendency for higher $\sigma_{0}$ values at lower $\alpha$ values (i.e. when the snow is wetter and/or grows older and becomes more metamorphosed). This corresponds to earlier observations that increasing surface wetness and roughness produces higher backscatter (e.g. Jezek and others, 1993; Rott and Davis, 1993).

Figure 3 shows two of the images that display high $\sigma_{0}$ over what we believe to be melting snow. All zones in these images follow the height contours of the ice cap (Fig. 1). The lowermost zone is bare glacier ice, as confirmed by AVHRR images acquired at most 1 week later. The uppermost zone (only in Fig. 3a) lies in the highest part of Vatnajökull, ap- 

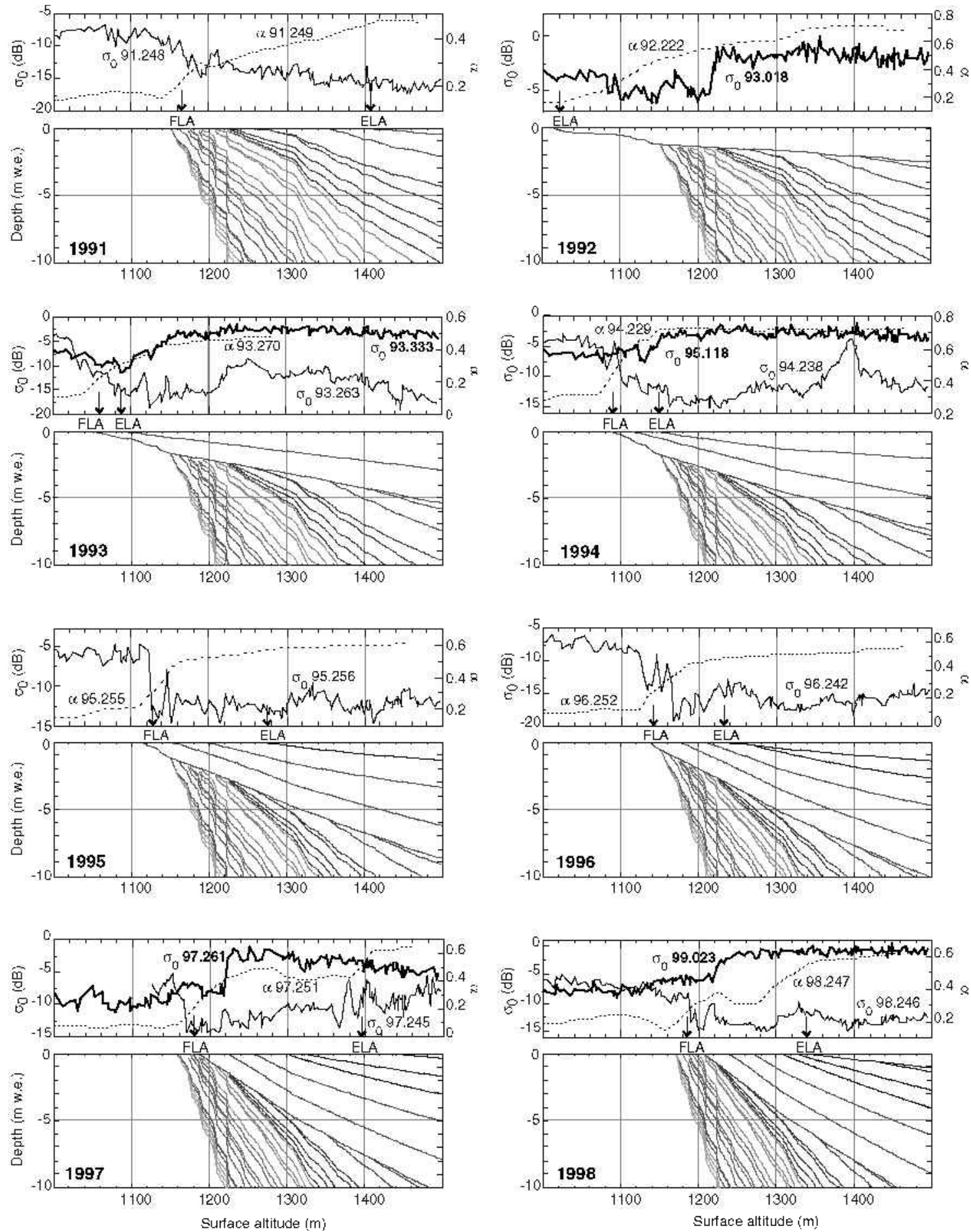

Fig. 4. Modelled stratigraphy, backscatter profiles ( $\sigma_{0}$, solid lines) and albedo profiles ( $\alpha$, dashed lines) along the transect over Bruarjökull shown in Figure 1. For each of the years 1991-98, annual layering at the end of the melting season (21 September) is shown. The $\sigma_{0}$ and $\alpha$ profiles are named by year and day of the year. For each year the profiles that display the highest firn line are shown. Some additional $\sigma_{0}$ profiles acquired in freezing conditions are shown as bold lines. $10 \mathrm{~m}$ in surface altitude approximately corresponds to $800 \mathrm{~m}$ in horizontal distance.

proximately above the $1600 \mathrm{~m}$ contour. From the daily mean temperature in Kirkjubæjarklaustur on the same day and assuming a lapse rate of $6^{\circ} \mathrm{C} \mathrm{km}^{-1}$, we find the daily mean $0^{\circ} \mathrm{C}$ isotherm to be at $1700 \mathrm{~m}$. The close correspondence of these two heights and the high $\sigma_{0}$ values suggest that the uppermost zone represents dry snow. If this is the case, then zones I-III probably consist of melting snow and/or melting firn. Zone I has low backscatter and corresponds to the initial-melt zone ("M") of Smith and others (1997). Zone II has high $\sigma_{0}(-6$ to $-10 \mathrm{~dB})$, but in both images it is bounded on both sides by zones of low $\sigma_{0}$. If the high backscatter in zone
II is caused by roughening elements like suncups (Ramage and others, 2000), then these must be absent in zone III. In this respect, zone II differs from the P2 zone found by Smith and others (1997), which lies directly above the bare-ice zone. In any case, most images that we purchased do not display zone II, and Hall and others (2000), who studied many SAR images of Hofsjökull, Iceland, do not mention such a zone either. The reason for this absence may be the regular occurrence of snowfall in the accumulation area during the summer, which may prevent the formation of suncups.

For further interpretation of the different boundaries 
that are present in the SAR images of Vatnajökull, we compare $\sigma_{0}$ profiles with $\alpha$ profiles and, following König and others (2001), with modelled stratigraphy. We do so for the western part of Brúarjökull, one of the large northern outlets, because this outlet mostly displays a rather sharp firn line. On other outlets the situation is more complicated, with a gradual and patchy firn-ice transition which makes it difficult to compare SAR images with model results.

\subsection{Stratigraphic modelling}

To model the stratigraphy we used mass-balance observations (since 1992) and mass-balance values (1960-92) obtained with a mass-balance model that was specially constructed for Vatnajökull (De Ruyter de Wildt and others, 2003). It describes the energy fluxes between atmosphere and glacier, which are tuned with in situ measured data (Oerlemans and others, 1999), in a detailed way. The most important model specifications are:

Temperature in the katabatic surface layer is related, but not equal, to the temperature in the free atmosphere just above the surface layer (in the surface layer, temperature is mostly lower and temperature variations are smaller than in the free atmosphere).

Incoming longwave radiation is a function of temperature in the free atmosphere, which is justified by the relatively thin katabatic layer over Vatnajökull.

Sensible-heat flux is a function of temperature in the katabatic layer.

Snow albedo depends upon the number of days since the last snowfall.

Ice albedo depends upon location and varies from very low in the northwest ( 0.10 due to volcanic ash layers) to 0.30 at some locations in the south and southeast.

Subsurface processes, such as refreezing of meltwater, are neglected and whenever the surface energy flux is positive, the surface is assumed to be at the melting point ("zero-degree assumption"). For a temperate ice cap like Vatnajökull, this is a reasonable assumption.

Free-air temperature and vapour pressure are assumed to be always horizontally (but not vertically) homogeneous over the ice cap. Meteorological data show that this is mostly the case. Cloudiness and relative variations in precipitation are also assumed to be horizontally homogeneous. This allows us to force the energy balance over the entire ice cap with data from one meteorological station.

The mean spatial distribution of precipitation over Vatnajökull is not well known, which is why we use this variable to calibrate the model to observations of the mass balance (Björnsson and others, 1997, 1998a,b, c, 1999). These observations were mainly made over the central and northwestern parts of the ice cap (i.e. the drainage basins of Tungnaárjökull, Köldukvíslarjökull, Dyngjujökull and Brúarjökull). Precipitation data from coastal weather stations in the south and southeast are available to prescribe a spatial distribution.

Daily mean temperature, humidity and cloudiness measured at Kirkjubæjarklaustur (Fig. 1) are used to drive the model. The spatial distribution of precipitation varies from year to year, so we force the model with the mean daily precipitation at three locations close to Vatnajökull (Kirkjubæjarklaustur, Fagurshólsmyri and Hornafjördur; see Fig. 1).

We modelled the stratigraphy at many points along the transect over western Brúarjökull (Fig. 1) which enables us to plot the stratigraphy as a function of surface elevation. We do not take ice flow into account, because Brúarjökull is in the quiescent phase of its surging cycle; the last surge took place in 1963 (about 4 km; Sigurðsson, 1998). Furthermore, the surface slope of Brúarjökull in the vicinity of the firn line is very low $\left(0.5-1^{\circ}\right)$, so mass is transported to lower surface elevations only very slowly.

\subsection{Comparison of SAR data with AVHRR data and stratigraphy}

In Figure 4 we compare backscatter profiles and albedo profiles along a flowline of western Brúarjökull with the reconstructed stratigraphy along the same flowline. Note that in each stratigraphy plot, the equilibrium line is given by the lower boundary of the most recent annual layer (the uppermost layer). Also note that annual-layer thickness is given in m w.e., which means that the compaction of firn into ice is not taken into account. On a temperate ice cap like Vatnajökull, the compaction process is complicated by melting and strong metamorphism of firn layers, which is very difficult to model. However, on other temperate glaciers the firn-ice transition often occurs in layers 4-13 years old, at depths of 13-32 $\mathrm{m}$ (Paterson, 1994). On the stratigraphy plots, we can observe that in 1991 the ELA was very high and the long-term firn line was present at the surface. In 1992, and to a lesser extent in 1993, the ELA was very low, and the long-term firn line was obscured by snow. It did not reappear until 1997, when most surface firn from 1992 had melted away. In 1997 and 1998 the firn-line altitude (FLA) at the end of the melting season was slightly higher than in 1991 due to melting of the lowermost surface firn layers in these two years.

In all years, the late-summer $\sigma_{0}$ and $\alpha$ profiles display a transition at the same altitude as the firn line (note that in 1993, 1996 and 1997 the SAR images were acquired some days before the AVHRR images). We therefore believe that the transitions on the summer $\sigma_{0}$ profiles coincide with the boundary between firn and ice to a good approximation. In all years except 1992, the equilibrium line lies above the firn line and cannot be seen on the $\sigma_{0}$ profiles. The $\alpha$ profiles only display the equilibrium line in 1997 and 1998. Note that in 1993 and 1994 the ELA was relatively low but nevertheless obscured by firn from 1992 (when the ELA was even lower).

Only at the end of the melting season in 1992 was all firn covered by snow, and for this year it should be possible to detect the snow-line on satellite images acquired at the end of the melting season. Unfortunately, we have no radar images for this year and we found no cloud-free AVHRR images for the end of the melting season. Images from the winter and spring of 1993 might also display the snow-line from 1992, because C-band microwaves can penetrate several metres through refrozen stratified dry snow and firn (e.g. Mätzler, 1987). However, the late-summer firn line is not visible on the image from 18 January 1993 (Fig. 4, panel for 1992). Near the end of August 1992, there was a considerable amount of snowfall, which contributed to the low ELA in 1992 (Björnsson and others, 1998c). This is confirmed by the modelled cumulative mass balance near the equilibrium 


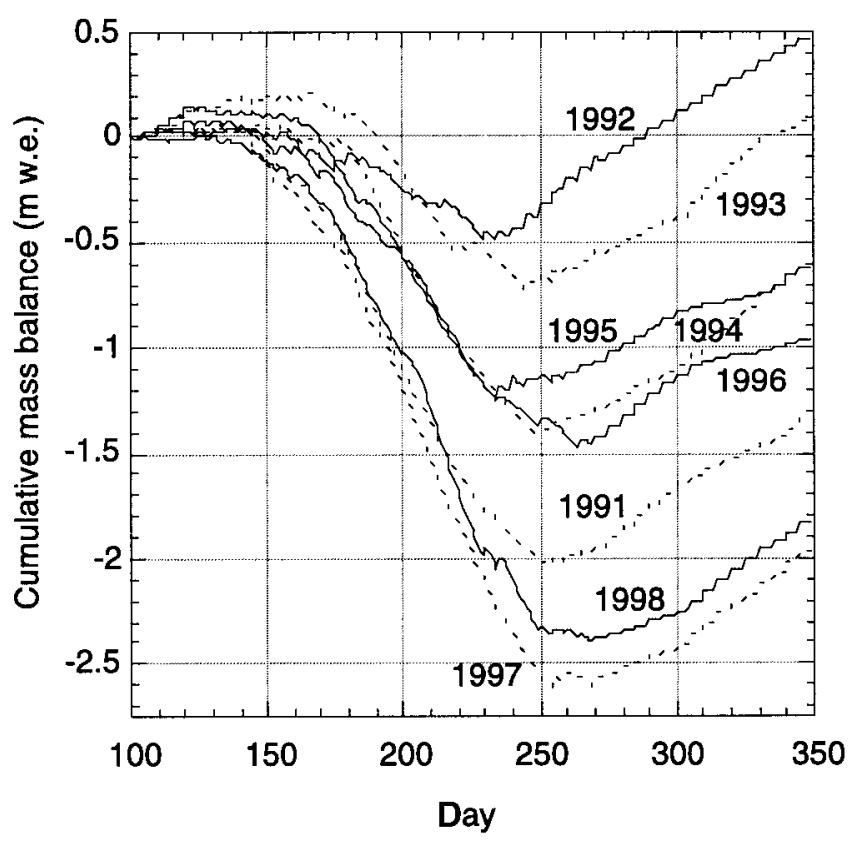

Fig. 5. Modelled cumulative mass balance at a site near the long-term firn line on western Brúarjökull. At day 100, a few weeks before the start of the melting season, the cumulative mass balance has been set to zero.

line, shown in Figure 5. The mass-balance model is forced with daily mean temperatures from Kirkjubæjarklaustur, and Figure 5 shows that there was no significant melting after August. Just above the 1992 equilibrium line, only a relatively thin layer of snow was present which did not experience significant melting during the autumn and formed the beginning of the winter snow pack. During the winter, the snowpack was nearly as thick just below the equilibrium line as just above it. It therefore seems unlikely that the late-summer snow can be distinguished from winter snow on the images from the winter and spring of 1993.

Although the image from 18 January 1993 does not display the equilibrium line from 1992, it does display two other boundaries: one at $1220 \mathrm{~m}$ and, somewhat less clear, one at 1150-1170 m (see Fig. 6). The lowermost boundary corresponds to the FLA from 1991 (which, according to Figure 5, was captured on days 248 and 249 at its highest position). We therefore assume that this boundary is the surface firn line. The uppermost boundary lies significantly higher and is also present in most other images that were acquired during freezing conditions (bold lines in Fig. 4). For example, images from the winters of $1997 / 98$ and 1998/99 also display a boundary at $1220 \mathrm{~m}$, which in both cases is higher than the FLA from the preceding summer. Again, Figure 5 shows that there was no substantial melting after the late-summer images were taken. Furthermore, the stratigraphy plots in Figure 4 display an increase in subsurface firn age at nearly the same altitude of $1225 \mathrm{~m}$. This increase may well correspond to an increase in density and we suppose that $1220 \mathrm{~m}$ is the lowest altitude where, during freezing conditions, the SAR sensor only "sees" firn and no ice. If this is correct, then just below this altitude the firn-ice transition lies closer to the surface and there the $\sigma_{0}$ signal stems both from ice and from the overlying firn. The winter $\sigma_{0}$ profiles for late 1993 and early 1995 do not show the transition at $1220 \mathrm{~m}$. On these images, it may be obscured by the thick pack of relatively recent firn. It is important to realize

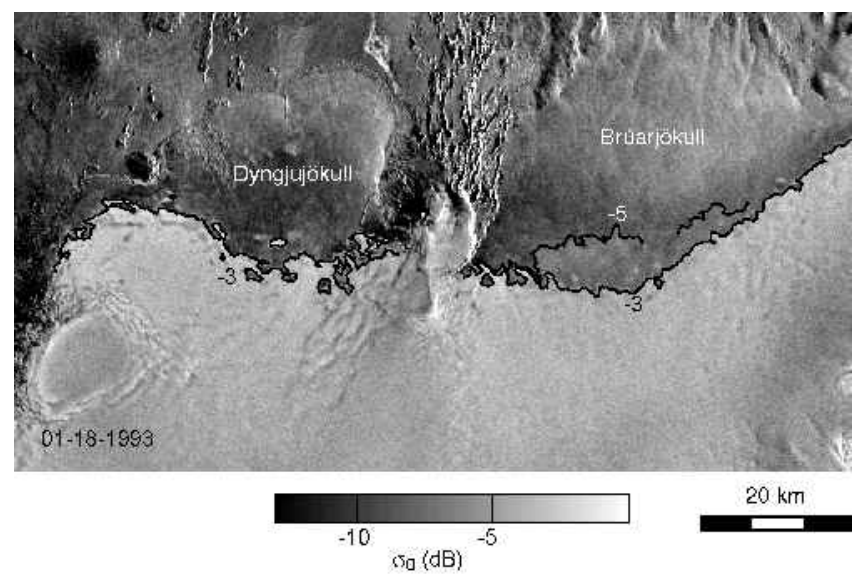

Fig. 6. ESA ERS $\sigma_{0}$ image of the northern part of Vatnajökull, acquired on 18 January 1993. (C) ESA 2002.

that the actual annual layers, especially the young layers, are thicker than shown in the stratigraphy plots because the stratigraphy in Figure 4 is displayed in m w.e.

Winter images from November 1993 (day 333; see panel for 1993) and April 1995 (day 118; see panel for 1994) do not display the late-summer firn line. The late-summer images from 1993 and 1994 display (nearly) the highest FLA, because according to Figure 5 there is no melting after 20 September 1993 (day 263) and very little after 26 August 1994 (day 238). The $\sigma_{0}$ profiles display a somewhat gradual transition, but in both years this begins above the FLA and ends at about $1160 \mathrm{~m}$ (the FLA from 1991). For both winters, this corresponds to a zone where the firn pack was relatively shallow. We therefore suggest that, in these two winters, above $1160 \mathrm{~m}$ only firn is detected, while below this altitude the influence of ice gradually increases.

During the winters of $1997 / 98$ and 1998/99 there was no shallow young firn pack to obscure the firn line, and the SAR images therefore display the surface firn line. The FLA in 1997 is almost the same as in 1991, and the image from 18 September 1997 (day 261, which was acquired during freezing conditions) displays a boundary close to this firn line. The image from 23 January 1999 (Fig. 7a) displays the same two boundaries as the other wintertime images, but the late-summer firn line from 1998 (3 September) lies midway between these two boundaries (Fig. 7b). Possibly the firn line moved up-glacier after 3 September, although little melt occurred after that date (Fig. 5).

\section{MASS-BALANCE RETRIEVAL}

It follows from Section 3 that SAR images are of limited use for annual detection of the equilibrium line. As a consequence, $B_{\mathrm{m}}$ can often not be inferred from radar images by using the linear relation between the ELA and $B_{\mathrm{m}}$ (Fig. 8). SAR images display the long-term firn line, but this is not related to $B_{\mathrm{m}}$ on an annual basis (Fig. 8). However, $B_{\mathrm{m}}$ may be related to other quantities that can be inferred from SAR images. Recent work (De Ruyter de Wildt and others, 2002) has shown that the average surface albedo of the ice cap during the melting season correlates well with $B_{\mathrm{m}}$. On the other hand, melting snow and firn tend to have higher $\sigma_{0}$ values when the albedo is lower (Fig. 2). In addition, Figure 9 shows that in years with a positive mass balance (e.g. 1993), the transient snow-line (TSL) rises more slowly and later in 

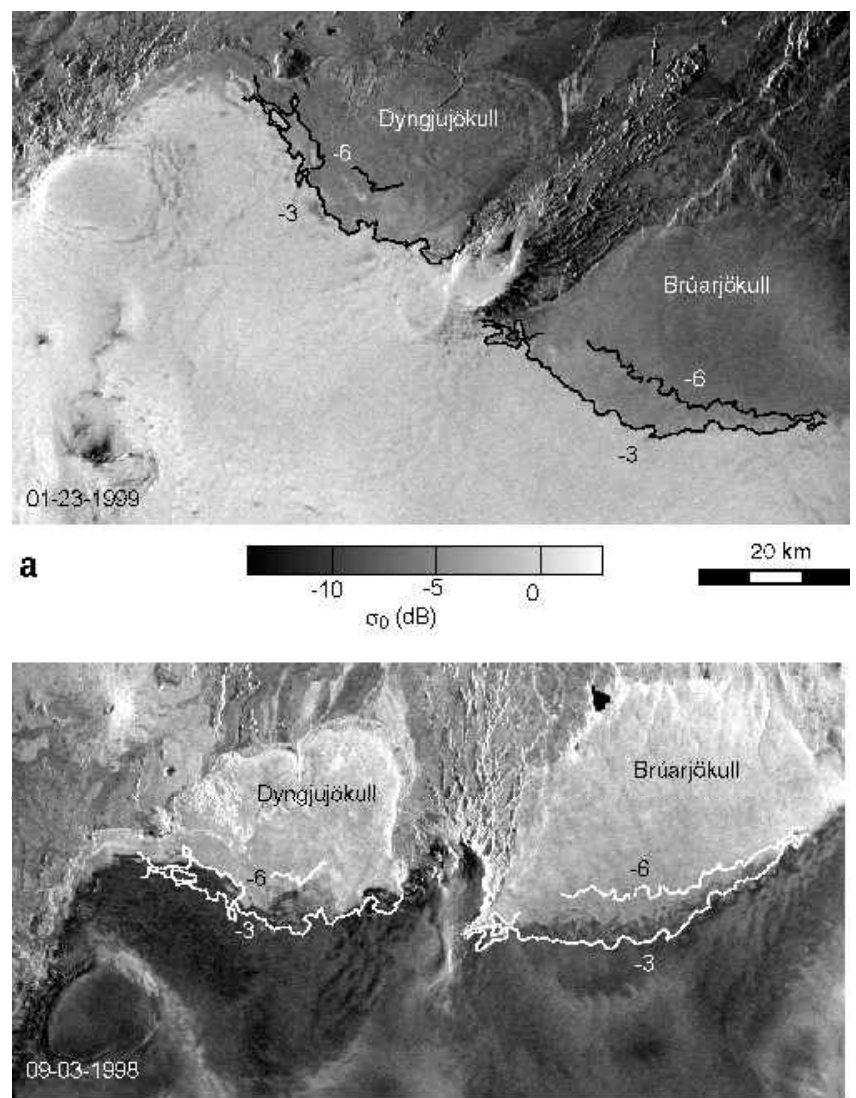

b

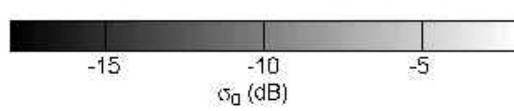

$20 \mathrm{~km}$

$\sigma_{0}(\mathrm{~dB})$

Fig. 7. ESA ERS $\sigma_{0}$ images of the northern part of Vatnajökull, acquired on 23 January 1999 (a) and 3 September 1998 (b). (b) is compared with $\sigma_{0}$ boundaries from (a). (C) ESA 2002.

the melting season than in years with a negative mass balance (e.g. 1997), resulting in a larger area of low $\sigma_{0}$ and hence a lower average $\sigma_{0}$. These observations suggest that during the melting season the average $\sigma_{0}$ over the glacier surface $\left(\left\langle\sigma_{0}\right\rangle\right)$ may be inversely proportional to $B_{\mathrm{m}}$. This can of course only be the case when dry snow and firn, and the P2 facies, are excluded from the analysis, as these facies disturb the negative correlation between $\sigma_{0}$ and $\alpha$ over melting glacier surfaces. Figure 10 shows that, for western Brúarjökull, $\left\langle\sigma_{0}\right\rangle$ generally increases during the summer, corresponding to increasingly high TSLs and/or snow and firn surfaces that are increasingly wet and rough. Only in 1993 was there no obvious increase and did $\left\langle\sigma_{0}\right\rangle$ remain relatively low during the summer. In this year, the summer was cold with regular snowfalls. In general, the signal strength changes with surface wetness and roughness, which are both highly dependent on temporal circumstances. This is shown, for example, by the data from 1998. In 1995 also $\left\langle\sigma_{0}\right\rangle$ was quite high in summer, while $B_{\mathrm{m}}$ had an intermediate value (Table 1). No suitable images are available for a large part of summer 1995, and the high $\left\langle\sigma_{0}\right\rangle$ values may not be representative. We can estimate the mean value of $\left\langle\sigma_{0}\right\rangle$ over the summer by interpolating $\left\langle\sigma_{0}\right\rangle$ between the successive images. We do so for days 195-245, which is the longest period for which $\left\langle\sigma_{0}\right\rangle$ values are available from each year. We then find a correlation coefficient of 0.72 between $\left\langle\sigma_{0}\right\rangle$, averaged over the summer, and $B_{\mathrm{m}}$. There is no significant correlation between $\left\langle\sigma_{0}\right\rangle$ and $B_{\mathrm{m}}$ for Dyngjujökull and Köldukvíslarjökull. This may be due to the short-term variability of the $\sigma_{0}$ signal or, alternatively, to the small number of SAR images for some years.

The most obvious feature on summertime SAR images is the boundary between the areas of high and low backscatter. This boundary closely corresponds to the boundary between the areas of low albedo (ice) and high albedo (snow/firn). It is formed by either the TSL or by the firn line (FL), and the position of this line contains, at least theoretically, information about $B_{\mathrm{m}}$. There are two arguments for this statement. First, the TSL-FL separates the low- and high-albedo areas, while the albedo strongly determines the amount of surface melt and hence the mass balance. Second, the position of the TSL-FL reflects the accumulation history of the preceding winter and the melt history of the current melting season. Figure 9 shows that the course of the TSL during the summer varies each year. During some melting seasons it rises faster and/or earlier than during others. As a result, the long-term firn line is exposed in some years and remains covered by snow in others. The position of the TSL can always be detected before it retreats to regions above the long-term firn line, so, for each year, much of the information about the accumulation and melt history that is present in the position of the TSL can be extracted. A
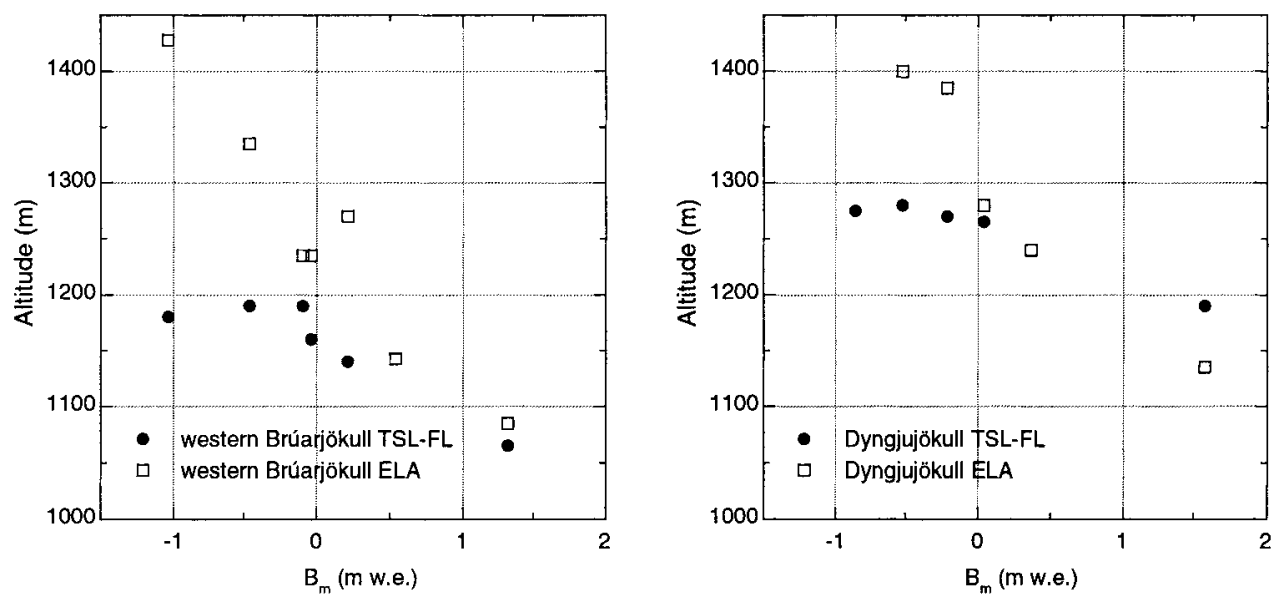

Fig. 8. Mean transient-snow-line-firn-line (TSL-FL) altitude at the end of the melting season, and ELA, as a function of the mean specific mass balance for western Brúarjökull and Dyngjujökull. Both radar and albedo images were used to derive TSLFL altitudes. ELAs are derived from the mass-balance measurements. 

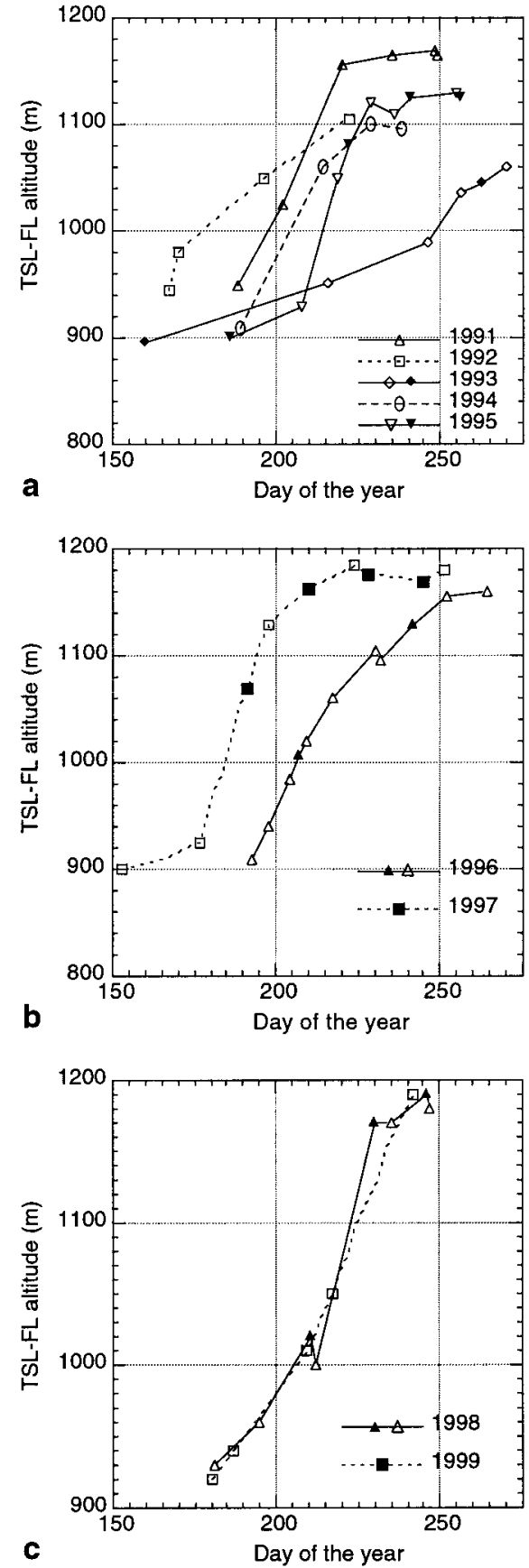

Fig. 9. TSL-FL altitude along the transect shown in Figure 1 (western Bruarjökull) as a function of the day of the year. Both backscatter images (solid symbols) and albedo images (open symbols) were used to obtain TSL-FL altitudes. Each TSL-FL altitude was manually determined as the altitude at which the change in backscatter or albedo was largest. Low TSL-FL altitudes in the latter part of the summer, indicative of summer snowfalls, are not shown.

simple way to quantify this is to compute the average altitude of the TSL-FL. We compute it for the second half of the melting season (days 200-264) because, in the year with the lowest $B_{\mathrm{m}}$ (1993), no ice was visible and hence no TSL existed before day 200. Dips in the altitude of the TSL-FL in the later part of the summer, indicative of summer snowfalls, are not used. These are often highly temporal events that are not representative of the previous and following weeks. When no images for the end of the melting season are available (e.g. 1992 and 1994), we linearly extrapolate the TSL altitude from those earlier in the melting season.

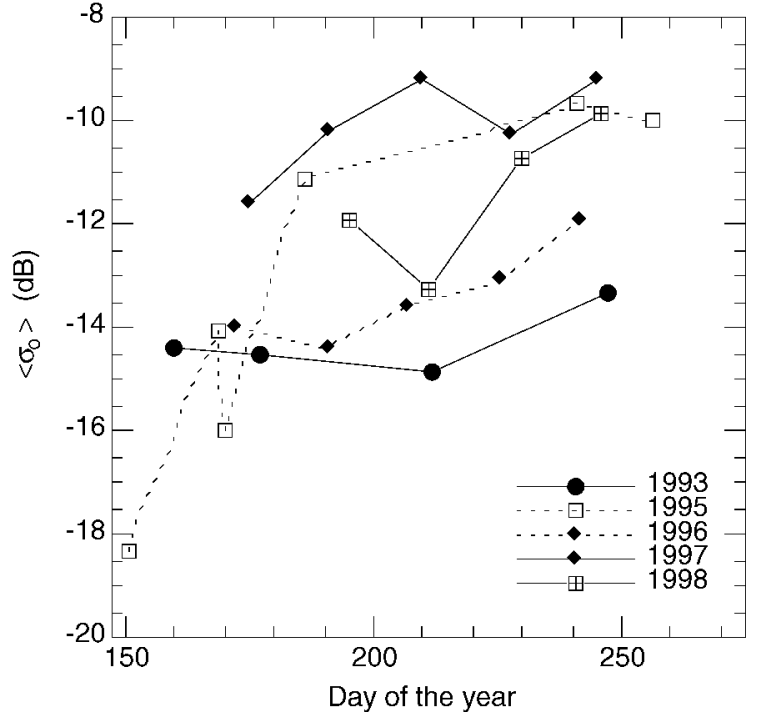

Fig. 10. Average $\sigma_{0}$ over western Brúarjökull as a function of day of the year, for each of the ERS SAR images. Only images that do not display dry snow and firn are used.

In such cases the long-term firn line (as seen during other years) forms an upper limit to the extrapolated TSL. Figure 11 shows that the resulting average altitudes of the TSL-FL during the second half of the melting season correlate well with $B_{\mathrm{m}}$ for several drainage basins.

\section{DISGUSSION AND CONGLUSIONS}

We have analysed many ERS SAR images by comparing them with AVHRR images, mass-balance observations and modelled firn stratigraphy. Both SAR and AVHRR images detect the TSL-FL as a distinctive boundary because the reflective and backscattering properties of melting snow and firn are different from those of bare glacier ice. However, we found no differences in backscatter and mostly no differences in reflectance between snow and firn. Therefore, when surface firn is present below the equilibrium line, the equilibrium line is not visible on SAR images and only occasionally visible on AVHRR images. We expect that the equilibrium line is visible on SAR images when no surface firn is present, but we have no SAR images available for the one year of the mass-balance series when this was the case (1992). Nevertheless, we can conclude that mass-balance retrieval through detection of the equilibrium line is often not possible. For seven years we have SAR images acquired near the end of the melting season, but on none of these could the equilibrium line of western Brúarjökull be detected. In two of these years the ELA was low, but it could not be detected because firn from a previous year was present at an even lower altitude. On AVHRR images, we could identify the equilibrium line of western Brúarjökull for only three out of nine years. The equilibrium line of other drainage basins of Vatnajökull could be seen on AVHRR images for even fewer years (De Ruyter de Wildt and others, 2002).

As well as the boundary between ice and melting snow and firn, SAR images can detect several boundaries that are not visible on albedo images. The intensity of the $\sigma_{0}$ signal is highly sensitive to the liquid-water content of snow, which makes it possible to detect the extent of surface melt (e.g. Steffen and others, 1993). For Vatnajökull this is of little use 


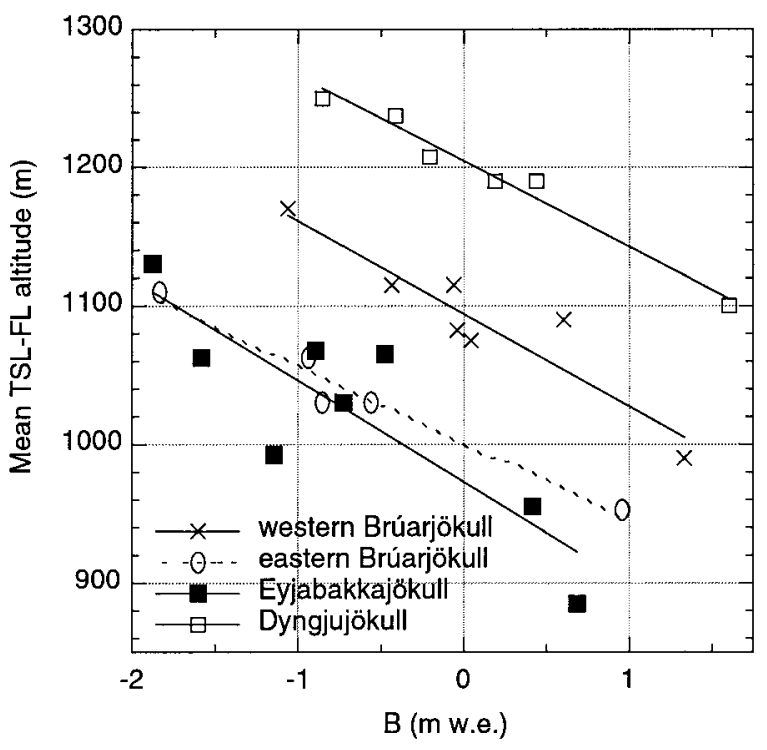

Fig. 11. Mean TSL-FL altitude during the second half of the melting season (days 200-264) as a function of the mean specific mass balance for western Brúarjökull, Dyngjujökull and Eyjabakkajökull. Both radar and albedo images were used to derive the TSL-FL altitude.

because all snow quickly starts to melt in late spring. A boundary between newly melting snow and roughened melting snow has been found elsewhere (Smith and others, 1997; Ramage and others, 2000). Although it may be present on some SAR images of Vatnajökull, most images do not display such a boundary. All of the boundaries mentioned above are surface boundaries. Subsurface boundaries can be detected when the surface is not melting, because then microwaves can penetrate several metres into the snow and scatter on subsurface structures. This is, for example, the case on images that display a dry winter snowpack. These images generally display the late-summer firn line, and also a distinctive boundary that lies at a somewhat higher elevation and seems to represent the subsurface continuation of the firn/ice transition. The late-summer surface firn line cannot be detected on some winter images, probably because in these cases the firn line lies below the long-term firn line. As a consequence, the firn pack is shallow just above the firn line (in other words, the firn/ice transition slopes only slightly with respect to the surface). This allows the penetrating microwaves to reach the underlying ice in the area directly above the firn line. On glaciers with steeper slopes than Brúarjökull, the surface firn line and any subsurface firn/ice transitions that may exist are probably inseparable. Such glaciers will tend to have a firn/ice transition that dips more with respect to the surface.

The equilibrium line is often not visible on SAR images, but nevertheless SAR images may be used in other ways to infer the mass balance. The intensity of the $\sigma_{0}$ signal is related to surface wetness (and roughness) and therefore to the amount of surface melt. For western Brúarjökull, we found a correlation between $B_{\mathrm{m}}$ and the mean $\sigma_{0}$ over the surface area and during part of the melting season, but for two other drainage basins no good correlation was found. It seems that, due to variable surface roughness and/or wetness, $\sigma_{0}$ is too variable in time to be a good proxy for $B_{\mathrm{m}}$, but no firm conclusion is possible until data from more years are available. At present, we have three to five years with both mass-balance and SAR data for each drainage basin.
In any case, the interannual variation of the SAR signal within the accumulation area is not as clearly related to $B_{\mathrm{m}}$ as the albedo. Hence, SAR images of Vatnajökull contain less information about $B_{\mathrm{m}}$ than albedo images.

The mean TSL-FL altitude during part of the melting season is found to be a better estimator of $B_{\mathrm{m}}$. This is the case for western Brúarjökull, Eyjabakkajökull and Dyngjujökull. On Tungnaárjökull, the transition from ice to snow and/or firn is often extremely patchy and gradual, making it impossible to derive a TSL-FL altitude. For Köldukvíslarjökull, we found too few usable images to obtain a usable correlation with $B_{\mathrm{m}}$. The reason is its hypsometry: the ice margin lies relatively high and bare ice appears relatively late in the summer. The period when the TSL lies between the ice margin and the long-term firn line is therefore short; once the TSL lies above the firn line, it is largely undetectable, while the detectable upper ice boundary is unrelated to the annual mass balance. On the other hand, in 1992 the TSL remained at a low altitude all summer and hardly reached the ice margin.

\section{AGKNOWLEDGEMENTS}

We gratefully acknowledge the following institutions and persons: H. Björnsson and O. Sigurðsson for providing mass-balance data, ESA for supplying ERS images, W. Greuell for sharing his expertise in AVHRR image processing and giving useful advice, T. Jonsson from the Icelandic Meteorological Office for providing climatological data, C. Reijmer for purchasing some of the AVHRR images, and A. Brooks and N. Lonie from the Satellite Receiving Station in Dundee for their technical support and selection of images. Two anonymous reviewers and the scientific editor $\mathrm{H}$. Rott provided useful comments. This work was funded by Space Research Organization Netherlands under project number eo-030.

\section{REFERENGES}

Adam, S., A. Pietroniro and M. M. Brugman. 1997. Glacier snow line mapping using ERS-1 SAR imagery. Remote Sensing Environ., 61 (1), 46-54.

Björnsson, H., F. Pálsson, M. T. Guðmundsson and H. H. Haraldsson. 1997. Afkoma, Hreyfing og afrennsli á vestan- og norðanverdum Vatnajökli jökulárid 1995-96. Reykjavík, Raunvísindastofnun Háskólans. (Report RH-2497.)

Björnsson, H., F. Pálsson, M.T. Guðmundsson and H. H. Haraldsson. 1998a. Mass balance and meteorological observations on Vatnajökull 1997. Reykjavík, University of Iceland. Science Institute. (Report RH-03-98.)

Björnsson, H., F. Pálsson, M.T. Guðmundsson and H. H. Haraldsson. 1998b. Mass balance and meteorological observations on Vatnajökull 1998. Reykjavík, University of Iceland. Science Institute. (Report RH-14-98.)

Björnsson, H., F. Pálsson, M.T. Guðmundsson and H. H. Haraldsson. 1998c. Mass balance of western and northern Vatnajökull, Iceland, 1991-95. Jökull, 45, 35-58.

Björnsson, H., F. Pálsson, M. T. Guðmundsson and H. H. Haraldsson. 1999. Mass balance and meteorological observations on Vatnajökull 1999. Reykjavík, University of Iceland. Science Institute. (Report RH-24-99.)

Demuth, M. and A. Pietroniro. 1999. Inferring glacier mass balance using RADARSAT: results from Peyto Glacier, Canada. Geogr. Ann., 81A(4), 521-540.

De Ruyter de Wildt, M. S., J. Oerlemans and H. Björnsson. 2002. A method for monitoring glacier mass balance using satellite albedo measurements: application to Vatnajökull, Iceland. f. Glaciol., 48(161), 267-278.

De Ruyter de Wildt, M. S., J. Oerlemans and H. Björnsson. 2003. A calibrated mass-balance model for Vatnajökull, Iceland. Fökull, 52, 1-20.

Fahnestock, M., R. Bindschadler, R. Kwok and K. Jezek. 1993. Greenland ice sheet surface properties and ice dynamics from ERS-1 SAR imagery. Science, 262(5139), 1530-1534.

Greuell, W., C. H. Reijmer and J. Oerlemans. 2002. Narrowband-to-broad- 
band albedo conversion for glacier ice and snow based on aircraft and near-surface measurements. Remote Sensing Environ., 82(1), 48-64.

Hall, D. K., R. S. Williams, Jr and O. Sigurðsson. 1995. Glaciological observations of Brúarjökull, Iceland, using synthetic aperture radar and thematic mapper satellite data. Ann. Glaciol., 21, 271-276.

Hall, D. K., R. S. Williams, Jr, J. S. Barton, O. Sigurðsson, L. C. Smith and J. B. Garvin. 2000. Evaluation of remote-sensing techniques to measure decadal-scale changes of Hofsjökull ice cap, Iceland. F. Glaciol., 46(154), 375-388.

Jezek, K. C., M. R. Drinkwater, J. P. Crawford, R. Bindschadler and R. Kwok. 1993. Analysis of synthetic aperture radar data collected over the southwestern Greenland ice sheet. F. Glaciol., 39(131), 119-132.

Knap, W. H., B.W. Brock, J. Oerlemans and I. C. Willis. 1999. Comparison of Landsat TM-derived and ground-based albedos of Haut Glacier d'Arolla, Switzerland. Int. 7. Remote Sensing, 20(17), 3293-3310.

Koelemeijer, R., J. Oerlemans and S. Tjemkes. 1993. Surface reflectance of Hintereisferner, Austria, from Landsat 5 TM imagery. Ann. Glaciol., 17, $17-22$.

Koks, M. 2001. Anisotropic reflection of radiation by melting snow. Landsat TM bands 2 and 4. (M.Sc. thesis, Universiteit Utrecht. Instituut voor Marien en Atmosferisch Onderzoek Utrecht (IMAU).)

König, M., J.-G. Winther, N.T. Knudsen and T. Guneriussen. 2001. Firnline detection on Austre Okstindbreen, Norway, with airborne multipolarization SAR. 7. Glaciol., 47(157), 251-257.

Laur, H. and 6 others. 1998. Derivation of the backscattering coefficient $\sigma^{\circ}$ in ESA ERS SAR PRI products. Fifth (b) edition. Noordwijk, European Space Agency. (ESA/ERIN Tech. Note 2; ES-TN-RS-PM-HL09, Rev. 5b.)

Mätzler, C. 1987. Applications of the interaction of microwaves with the natural snow cover. Remote Sensing Rev., 2, 259-387.

McClatchey, R. A., R. W. Fenn, J. E. A. Selby and J. S. Garing. 1972. Optical properties of the atmosphere. Vol. D12. 3rd edition. Hanscom AFB, MA, Air Force Cambridge Research Laboratory. (AFCRL Rep. 72-0497, Environ. Res. Pap. 411.)

Oerlemans, J. and 7 others. 1999. Glacio-meteorologicalinvestigations on Vatnajökull, Iceland, summer 1996. Boundary-Layer Meteorol., 92(1), 3-26.

Østrem, G. 1975. ERTS data in glaciology - an effort to monitor glacier mass balance from satellite imagery. F. Glaciol., 15(73), 403-415.

Partington, K. C. 1998. Discrimination of glacier facies using multi-temporal SAR data. 7. Glaciol., 44(146), 42-53.

Paterson, W. S. B. 1994. The physics of glaciers. Third edition. Oxford, etc., Elsevier.
Ramage, J. M., B. L. Isacks and M. M. Miller. 2000. Radar glacier zones in southeast Alaska, U.S.A.: field and satellite observations. 7. Glaciol., 46(153), 287-296.

Rao, G. R. N. and J. Chen. 1995. Inter-satellite calibration linkages for the visible and near-infrared channels of the Advanced Very High Resolution Radiometer on the NOAA-7, -9 and -11 spacecraft. Int. 7. Remote Sensing, 16(11), 1931-1942.

Rao, G. R. N. and J. Chen. 1999. Revised post-launch calibration of the visible and near-infrared channels of the Advanced Very High Resolution Radiometer (AVHRR) on the NOAA-14 spacecraft. Int. 7. Remote Sensing, 20(18), 3485-3491.

Reijmer, C. H. 1997. The surface albedo of the Vatnajökull ice cap, Iceland: a comparison between satellite-derived and in situ measurements. Utrecht, Universiteit Utrecht. Instituut voor Marien en Atmosferisch Onderzoek Utrecht (IMAU). (Internal Report V97-11.)

Rott, H. and R. E. Davis. 1993. Multifrequency and polarimetric SAR obervations on alpine glaciers. Ann. Glaciol., 17, 98-104.

Rott, H. and G. Markl. 1989. Improved snow and glacier monitoring by the Landsat thematic mapper. In Proceedings of a Workshop on "Earthnet Pilot Project on Landsat Thematic Mapper Applications", held at Frascati, Italy in December 1987. Noordwijk, Netherlands, European Space Agency, 3-12. (ESA SP-1102.

Rott, H. and C. Mätzler. 1987. Possibilities and limits of synthetic aperture radar for snow and glacier surveying. Ann. Glaciol., 9, 195-199.

Rott, H., G. Domik, C. Mätzler, H. Miller and K. G. Lenhart. 1985. Study on the use and characteristics of SAR for land snow and ice applications. Final report. Paris, European Space Agency. (ESA Report 5441/83/D/IM/SC.

Sigurðsson, O. 1998. Glacier variations in Iceland 1930-1995: from the database of the Iceland Glaciological Society. Fökull, 45, 3-25.

Sigurðsson, O. 1999. Jöklabreytingar 1930-1960, 1960-1990 og 1995-1996 [Glacier variations 1930-1960, 1960-1990 and 1995-1996]. Fökull, 47, $101-107$

Smith, L. C., R. R. Forster, B. L. Isacks and D. K. Hall. 1997. Seasonal climatic forcing of alpine glaciers revealed with orbital synthetic aperture radar. F. Glaciol., 43(145), 480-488.

Steffen, K., W. Abdalati and J. Stroeve. 1993. Climate sensitivity studies of the Greenland ice sheet using satellite AVHRR, SMMR, SSM/I and in situ data. Meteorol. Atmos. Phys., 51, 239-258.

Stiles, W. H. and F.T. Ulaby. 1982. Dielectric properties of snow. CRREL Spec. Rep., 82-18, 91-103.

MS received 3 May 2002 and accepted in revised form 7 July 2003 